\title{
Brachytherapy in the treatment of skin cancer: an overview
}

\author{
Janusz Skowronek ${ }^{1,2}$ \\ ${ }^{1}$ Brachytherapy Department, Greater Poland Cancer Center, Poznan, Poland \\ Head of the Department: Prof. Janusz Skowronek MD, PhD \\ Electroradiology Department, Poznan University of Medical Sciences, Poznan, Poland \\ Head of the Department: Prof. Julian Malicki MD, PhD
}

Postep Derm Alergol 2015; XXXII (5): 362-367

DOI: $10.5114 / p d i a .2015 .54746$

\begin{abstract}
The incidence of skin cancer worldwide is constantly growing and it is the most frequently diagnosed tumor. Brachytherapy (BT) in particular localizations is a valuable tool of the exact radiation depot inside the tumor mass. In localizations such as the face, skull skin and inoperable tumors, relapses after surgery, radiotherapy are usually not suitable for primary or secondary invasive treatment. Brachytherapy is a safe procedure for organs at risk according to rapid fall of a dose outside the axis of the applicator with satisfactory dose localization inside the target. The complications rate is acceptable and treatment costs are low. In some tumors (great skin lesions in the scalp, near eyes or on the nose) BT allows for a great dose reduction in surrounding healthy tissues. Brachytherapy provides minimal dose delivery to surrounding healthy tissue, thus enabling good functional and cosmetic results. Treatment is possible almost in all cases on an outpatient basis.
\end{abstract}

Key words: electronic brachytherapy, high dose rate brachytherapy, pulsed dose rate brachytherapy, radiotherapy, skin cancer.

\section{Purpose}

Nonmelanoma skin cancer (NMSC) is the most common malignancy and affects $2-3$ million people each year only in the United States. The incidence is underestimated in many countries. Although NMSC has a low mortality rate, its incidence continues to rise; it significantly affects quality of life. Basal cell (BCC) and squamous cell carcinomas (SCC) of the skin usually occur on sun-exposed areas, the face being one of the sites of predilection, accounting for $95 \%$ of cases. Surgery in these sites (nose, ears, eyelids, lips) may be mutilating or require complex plastic reconstruction techniques under general anesthesia [1-4]. Radiation therapy has been used to treat NMSC for more than 40 years, and different techniques include superficial X-rays, orthovoltage X-rays, megavoltage photons, electron beam irradiation, and HDR brachytherapy (BT). Radiotherapy (RT), in particular a well-planned BT, is often the treatment of choice in cases of skin cancer which cannot be surgically removed without serious defects, cosmetic and reconstructive procedures [5-7]. There are many techniques of radiation that can be used to treat skin cancers. In external beam radiation therapy
(EBRT), partial or photon radiation obtained from linear accelerators is used. In contrast, BT (from Greek - close, in French - curietherapy) uses the energy of photons or particles coming from the decay of radioactive isotopes located in the tumor (BT interstitial) or in its immediate proximity (BT superficial) [5-7].

Before starting the treatment of skin cancer, radiation therapy should be considered by a number of clinical parameters such as the total dose of radiation, dose fractionation, dose distribution, the size of the treated field, the beam type and the total treatment time, because they have a significant impact on the final results of therapy [8]. External beam radiation therapy has several adverse features, which include a decrease in the dose to the skin surface requiring the use of bolus doses, greater absorption by the bones and decrease in the dose on the perimeter of the field in the case of inclined surfaces [9]. In addition, ionizing radiation can penetrate deeply, potentially injuring adjacent tissue and organs causing brain and bone necrosis. Differences in the dose distribution after the application of $6 \mathrm{MeV}$ electrons (EBRT) and high dose rate (HDR) BT (HDR-BT) are shown in Table 1.

Address for correspondence: Prof. Janusz Skowronek MD, PhD, Brachytherapy Department, Greater Poland Cancer Center, 15 Garbary St, 61-866 Poznan, Poland, phone: +48 6188508 18, +48 602618 538, fax: +48 61885 08 34, e-mail: janusz.skowronek@wco.pl Received: 17.10.2014, accepted: 26.12.2014. 
Dose distribution is more favorable for HDR due to better protection of subcutaneous tissues (bones, ligaments, joints, lacrimal gland, etc.) located close to the tumor being treated. Brachytherapy is better than EBRT in tumor radiation coverage and is connected with a lower complications rate. After BT, recurrence rates for NMSC are low, especially for small, superficial lesions, with good to excellent functional and cosmetic results.

\section{Indications for brachytherapy}

The basis for the HDR-BT of NMSC is TNM clinical classification. For this reason, in the preparatory proceedings, the clinical stage should be assessed, accurate measurements made, lesions documented photographically if possible, and in case of the suspicions of deep infiltration of the eye, ear or other structures, computed tomography should be considered [5].

Brachytherapy is a valued method due to the excellent results and very good cosmetic effects after treatment of unfavorably located cancer [10-13]. Brachytherapy is a method recommended in situations where changes are localized on anatomical curves and near critical organs (nasal bridge, periorbital region and skin of the chest) [14]. It also enables treatment of large tumors with minimal detriment of healthy tissues and a high probability of cure without adverse local complications [15]. In many clinical situations, BT is the only possibility we can offer after recurrence previously treated with RT.

Basic indications for BT are: 1. radical sole (mono) BT of T1-2NO tumors (primary lesions, recurrences after surgery and/or radiotherapy); 2 . adjuvant therapy after non radical surgery; 3 . as a boost in larger tumors (T2-T3) or in TxN1 cases after EBRT to the primary tumor and lymph nodes; 4. palliative treatment (Table 2).

\section{Contraindications for brachytherapy}

1. Malignant melanoma of the skin which is not radiosensitive (except in chosen cases of treatment combined with hyperthermia, after non radical surgery); 2. Skin cancers invading bony structures; 3 . Upper eyelid lesions; 4. Pinna tumour involving both the concha and the external auditory canal, ear conduct or any other site where the anatomical situation makes the source positioning needed to provide adequate covering of the target volume impossible [16].

\section{Brachytherapy techniques}

Brachytherapy with radioactive Ir-192 isotope (source) is applied to small skin cancer lesions, using surface applicators, I.e. Freiburg/French, Leipzig or Valencia type. New developments in the field of radiotherapy for skin cancer include electronic BT [17].

Continuous technological advances in recent years in the field of BT allowed us to the use well-prepared
Table 1. Dose distribution of $6 \mathrm{MeV}$ electrons (EBRT) (with $0.5 \mathrm{~cm}$ bolus) and HDR-BT (Freiburg applicator, distance between applicator and skin surface $-5 \mathrm{~mm}$ ) [9]

\begin{tabular}{ccc}
\hline Depth $[\mathrm{cm}]$ & $\begin{array}{c}\text { Electrons 6 MeV, } \\
\text { \% dose }\end{array}$ & $\begin{array}{c}\text { HDR-BT (normalized on } \\
\text { 0.2 cm depth), \% dose }\end{array}$ \\
\hline 0.0 & 88 & $105-110$ \\
\hline 0.5 & 98 & 85 \\
\hline 1.0 & 98 & 65 \\
\hline 1.5 & 78 & 55 \\
\hline 2.0 & 36 & 30 \\
\hline
\end{tabular}

applications of radioactive sources (usually Ir-192) using after-loading techniques (automatic source loading systems) $[18,19]$. Under the control of a computer system for treatment planning, a single source is inserted into all previously established applicators and positioned on the basis of the planned treatment area. The source moves along the guide axis at a given distance, which is roughly equal to the tumor size [16]. General principles of treatment planning include extending the tumor with an applicator, applicator stabilization (interstitial or superficial), the treatment dose covering the tumor with an adequate margin. Currently, the most commonly used BT techniques are HDR using radioactive isotopes Ir-192 or Co-60 with the original activity of $370 \mathrm{Gbq}(10 \mathrm{Ci})$ and dose rate $>12 \mathrm{~Gy} / \mathrm{h}$ and pulsed dose rate (PDR), which uses the same isotope, but with a lower activity level of 15-37 Gbq (0.5-1 Ci).

\section{Superficial brachytherapy}

Among the several techniques of superficial BT, different applicators are used: 1. mats (made of classical catheters and adhesive tape), useful in the treatment of large and flat surface; 2 . shapes and forms to allow irradiation of the surrounding area of irregular shapes (e.g. pinna); 3. surface applicators individually tailored to the individual patient or commercial ones (Brock applicators, Leipzig, Freiburg, HAM). A typical applicator comprises 2-10 parallel positioned catheters (filled during the irradiation with a radioactive source sequentially) with an equal distance

Table 2. Indications for radiotherapy (both - EBRT and BT) in a group of skin tumors based on histopathology [6]

\begin{tabular}{|c|c|c|}
\hline $\begin{array}{l}\text { Highly } \\
\text { recommended }\end{array}$ & Recommended & $\begin{array}{c}\text { Rarely } \\
\text { recommended }\end{array}$ \\
\hline $\begin{array}{c}\text { Sarcoma Kaposi } \\
\text { Mycosis } \\
\text { fungoides } \\
\text { Lymphomas }\end{array}$ & $\begin{array}{l}\text { BCC/SCC (except } \\
\text { scrotum, soles of the } \\
\text { feet and hand) } \\
\text { Bowen disease/ } \\
\text { erythroplasia } \\
\text { Angiosarcoma } \\
\text { Merkel cell carcinoma }\end{array}$ & $\begin{array}{l}\text { Fibrosarcoma, } \\
\text { BCC/SCC of } \\
\text { scrotum, soles of } \\
\text { the feet and hand } \\
\text { Melanoma (except } \\
\text { treatment after } \\
\text { non radical } \\
\text { surgery) }\end{array}$ \\
\hline
\end{tabular}

SCC - Squamous cell carcinoma, BCC - basal cell carcinoma. 


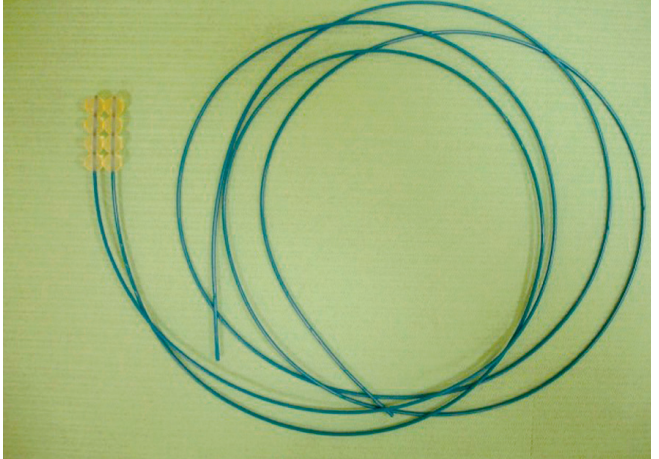

Figure 1. Applicator for superficial brachytherapy built of the Freiburg applicator and French 5 applicator (Nucletron, an Elekta company, Elekta AB, Stockholm, Sweden)

of 5-10 mm preserved between them. Examples of some applicators are presented in Figures 1 and 2.

Applicators are designed for flat surfaces and do not require anesthesia during application. Similarly, the pulmonary French applicators can also be used for the treatment of lesions located on the skin surface. When the applicator is ready, markers are placed in the catheters simulating the radioactive source and $\mathrm{X}$-rays (front-rear and lateral) or computed tomography (CT)-scans are performed and the obtained data are transferred to the planning system. At this stage the irradiated area (planning target volume - PTV) consists of a tumor and $0.5 \mathrm{~cm}$ or $1 \mathrm{~cm}$ margin (gross tumor volume - GTV) depending on the lesion diameter) [20, 21].

According to the recommendations of the American Brachytherapy Society, tumors with an infiltration depth $<0.5 \mathrm{~cm}$ can be treated with superficial BT alone. The suggested dose is 48-51 Gy/16-17 fractions $/ 0.5 \mathrm{~cm}$ from the surface of the applicator given once daily [22].

\section{Interstitial brachytherapy}

Tumors located on the curved surfaces (naso-buccal folds, fingers, ear pinna) with a diameter of $5-6 \mathrm{~cm}$ and a thickness of $0.5-2.0 \mathrm{~cm}$ should be treated with interstitial BT. The cases of coexisting fistula, nodal metastasis and bone infiltration are excluded here. Most cancers can be treated by 1 to 3 plastic applicators implanted into the tumor for which the prescribed dose of 65 Gy (45$70 \mathrm{~Gy}$ ) to the reference isodoses $85 \%$ is calculated according to the Paris system. Such proceedings bring benefits in terms of local control in the range of $95-98 \%$ with an excellent cosmetic and functional result [23].

In the interstitial method, specially phrasing hypodermic needles bevel of 2-10 cm in length, silk and nylon wire tubes adapted for after-loading applications are still used in some centers. All applications are performed in local or general anesthesia (if necessary). The same is true in the case of metal applicators used for interstitial implantation of radioactive iridium wires with a thickness

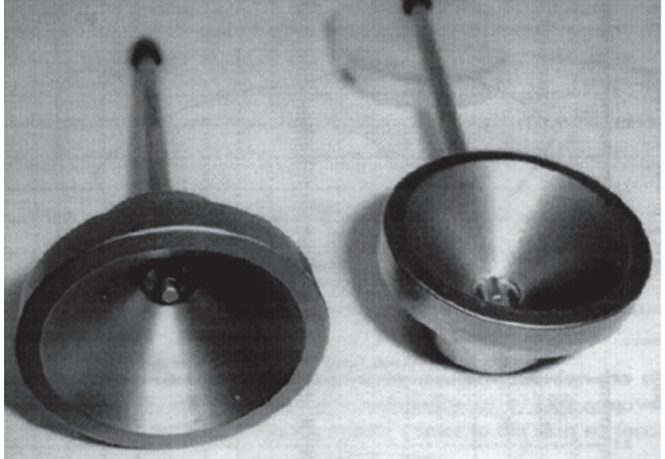

Figure 2. Photography of the horizontal $(\mathrm{H} 30)$ and perpendicular (V30) Leipzig applicators with a $30 \mathrm{~mm}$ conediameter (Nucletron, an Elekta company, Elekta AB, Stockholm, Sweden)

of $0.5 \mathrm{~cm}$. The number of applicators or needles depends on the tumor diameter and in most skin cancers infiltrating less than $1 \mathrm{~cm}$ healthy tissues, single plane HDR applications are performed. Standard doses range for T1-2 tumors - 48 Gy/16 fractions/2 times daily and for the tumors T3-4 - 51 Gy/17 fractions/2 times daily [16, 24].

\section{Electronic brachytherapy}

High-dose-rate (HDR) electronic BT (EBT) using surface applicators for the treatment of NMSC is a relatively new technique. Electronic brachytherapy was developed in the last years to provide patients with a shorter treatment schedule and physicians with a more convenient form of BT that does not require radioactive isotopes or dedicated treatment vaults $[25,26]$.

Bhatnagar [25] in one of the first publications analyzed a group of 122 patients with 171 lesions treated with EBT. They were treated with EBT up to a dose of $40 \mathrm{~Gy}$ in eight fractions, delivered twice weekly. There have been no recurrences within a mean follow-up of 10 months (range: 1-28 months). No Grade 3 or higher adverse events were observed at any time point. The EBT system used for this study (Axxent eBx; Xoft-a subsidiary of iCAD, Inc., Sunnyvale, CA, USA) uses a miniaturized $X$-ray source at its tip, capable of delivering HDR and low energy radiation without the use of radioactive isotopes.

Garcia-Martinez et al. [26] presented the new Esteya ${ }^{\oplus}$ Electronic Brachytherapy System (Esteya EBS, Elekta ABNucletron, Stockholm, Sweden) with excellent flatness and penumbra as with the Valencia applicator case, combined with an improved percentage of depth dose (PDD), allowing treatment of lesions of up to a depth of $5 \mathrm{~mm}$ in combination with reduced treatment duration. The Esteya ${ }^{\oplus}$ Electronic Brachytherapy System consists of a treatment unit with surface applicators, a user interface with planning software and a treatment control panel (Figure 3). The new Esteya system of electronic BT shows excellent flatness and penumbra as in the Valencia applicator case, but with an improved PDD (allowing treatment of lesions 
up to $5 \mathrm{~mm}$ deep) and increased dose rate (reducing the treatment time). Because of the low energy of the Esteya system it allows HDR-BT superficial treatment within a minimally shielded environment [26].

\section{Published results}

\section{Greater Poland Cancer Center (GCC) own results [27]}

Four hundred and ninety-seven patients with skin cancer were treated in GCC between November 1999 and April 2008. The group consisted of 257 men and 240 women in the age range of 44-97 years (mean: 72 years). $96.57 \%$ of patients were treated radically, and $3.43 \%$ - palliatively. The most frequent pathologic types observed were BCC $(n=233,48.09 \%)$ and SCC $(n=118,23.74 \%)$. Thirteen cases of skin cancer were qualified to HDR-BRT after previous external beam radiation treatment. Sixty-three (12.76\%) patients were treated as a supplementary therapy, after the surgery procedure. The dose reached 50-60 Gy in 10 fractions $(n=430,86.52 \%)$ and $30-40$ Gy in 6-8 fractions ( $n=67,13.48 \%$ ). The reference point of the dose was estimated on $1 \mathrm{~cm}$. Complete remission (CR) after 12 months appeared in 356 (71.63\%) patients, progression - in 73 (4.63\%). All patients experienced early skin reaction after radiation treatment according to RTOG classification: 1 degree - 372 (74.8\%), 2 degree - 81 (16.3\%), 3 degree 44 (8.9\%). Late skin reactions were observed as follows: 1 degree $(n=388,78.1 \%), 2$ degree $(n=85,17.1 \%)$ and 3 degree $(n=24,4.9 \%)$.

\section{Other results}

Many published studies confirm the high percentages of the cure rate using skin cancer BT. Selected results are shown in Table 3.

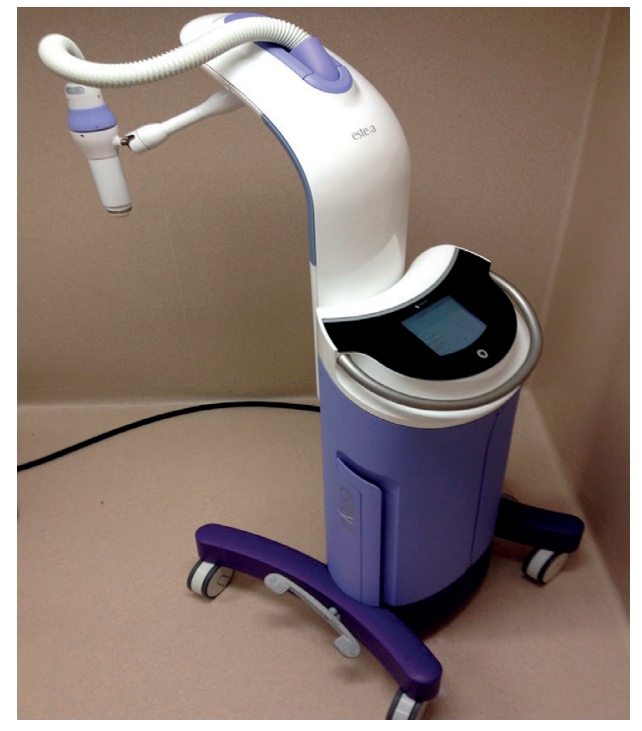

Figure 3. The Esteya Electronic Brachytherapy System (Nucletron, an Elekta company, Elekta AB, Stockholm, Sweden) [6]

In stage T1-T2 (total dose of 60-65 Gy), 5-year local control is achieved in over $95 \%$ of cases [15, 28-31]. In treatment of recurrences after the previous surgery failure, rates are slightly higher and range from $6 \%$ to $13 \%[15,29,33]$.

Selected publications are worth discussing. Guix et al. in a group of 136 patients with primary and recurrent cancers treated using superficial applicators showed that the probability of a local cure is $99 \%$ and $87 \%$, respectively [15]. The percentage of early and late complications was low. Only in $2 \%$ of patients in the group of patients with recurrent skin cancer, with a diameter greater than $4 \mathrm{~cm}$, an

Table 3. Selected results of skin cancer brachytherapy [1]

\begin{tabular}{|c|c|c|c|c|c|}
\hline Author & Location & $N$ & Technique & Follow-up [years] & Local control \\
\hline Guix [15] & Face & 136 & HDR & 5 & $\begin{array}{c}99 \% \text { - primary } \\
87 \% \text { - recurrence }\end{array}$ \\
\hline Crook [28] & Nose & 468 & HDR & 5 & $97.5 \%$ \\
\hline Debois [29] & Nose & 370 & LDR & 2 & $\begin{array}{c}97 \% \text { - primary } \\
94 \% \text { - recurrence }\end{array}$ \\
\hline Gambaro [30] & Eyelid & 50 & HDR & 6.5 & $96 \%$ \\
\hline Maes [31] & Face & 173 & HDR & 3.5 & $95 \%$ \\
\hline Ashby [32] & Vary & 642 & Radium & & $96.8 \%$ \\
\hline Daly [33] & Eyelid & 165 & HDR & 5 & $\begin{array}{c}97 \% \text { - primary } \\
94 \% \text { - recurrence }\end{array}$ \\
\hline Svoboda [34] & Vary & 76 & HDR & 9.6 & $96.2 \%$ \\
\hline Mazeron [35] & Ear & 70 & HDR & 5 & $99 \%$ \\
\hline Tormo [36] & Vary & 32 & HDR & 2 & $98 \%$ \\
\hline Gauden [37] & Vary & 200 & HDR (Leipzig) & 5.5 & $98 \%$ \\
\hline Arguis [38] & Vary & 141 & HDR (Leipzig) & 3.25 & $92.4 \%$ \\
\hline
\end{tabular}


Table 4. Cosmetic results and complications after brachytherapy of skin cancer [1]

\begin{tabular}{|c|c|c|c|c|c|}
\hline Author & Location & $N$ & Technique & Good cosmetic result & Complications rate \\
\hline Guix [15] & Face & 136 & HDR & & $0 \%$ \\
\hline Maes [31] & Face & 173 & HDR & $89 \%$ & $3.6 \%$ \\
\hline Debois [29] & Nose & 370 & LDR & & $0 \%$ \\
\hline Crook [28] & Nose & 468 & HDR & $94 \%$ & $2 \%$ \\
\hline Daly [33] & Eyelid & 165 & HDR & & $\begin{array}{l}13 \% \text { - primary } \\
31 \% \text { - recurrence }\end{array}$ \\
\hline Gambaro [30] & Eyelid & 50 & HDR & $92 \%$ & $\begin{array}{c}4 \%-\text { cataract } \\
20 \%-\text { chronic inflammation of the mucous } \\
\text { membranes } \\
25 \%-\text { lacrimal duct stenosis }\end{array}$ \\
\hline Mazeron [35] & Ear & 70 & HDR & $\begin{array}{l}<4 \mathrm{~cm}: 78 \% \\
>4 \mathrm{~cm}: 11 \%\end{array}$ & $\begin{array}{c}13 \% \text { - transient ulcers } \\
4 \% \text { - necrosis }\end{array}$ \\
\hline
\end{tabular}

unsatisfactory cosmetic result was achieved. At the same time, dosimetric studies demonstrated that the differences between the minimum and maximum radiation dose at a depth of $5 \mathrm{~mm}$, even in the case of major anatomical curves do not exceed $3 \%$. The high dose uniformity in such cases is not possible to be obtained after application of photons or electrons with low-energy irradiation.

Daly et al. [33] published the results of treatment of 165 patients with skin cancer of the eyelids. The local control was $96 \%$ (6/165 recurrences). Acute treatment toxicity was observed in 49/165 (30\%) patients at 8 weeks after treatment, lasting in 3\% for more than 4 months. In most cases, the cosmetic effect and the preservation of activity of eyelids was considered as good or very good. Severe late complications occurred in 30 (18\%) patients, in some cases requiring the intervention of the surgeon. Rio et al. [24] performed a retrospective analysis of 97 skin carcinomas (88 BCC, 9 SCC) of the nose, periorbital areas, and ears from 40 previously untreated patients (group 1) and 57 patients who had undergone surgery (group 2). The average dose was 55 Gy (range: 50-65 Gy) in group 1 and 52 Gy (range: 50-60 Gy) in group 2. The local control was $92.5 \%$ in group 1 and $88 \%$ in group 2 (median follow-up 55 months; range: 6-132 months). Five-year disease-free survival was better in group 1 (91\%; range: $75-97)$ than in group 2 (80\%; range: $62-90 ; p=0.23)$. Authors have concluded that BT provided a high level of local control and good cosmetic results for facial periorificial skin carcinomas that pose problems of surgical reconstruction.

\section{Cosmetic effect}

The cosmetic effect in the vast majority of reported cases (range: 78-92\%) is defined as good or very good (Table 4). A particularly high risk of complications occurs when the tumor is located on the eyelids (cataracts, chronic inflammation of mucous membranes, lacrimal duct stenosis). For small tumors (T1-T2), one should be aware of not exceeding a total dose of $60 \mathrm{~Gy}$, as higher doses significantly influence the increase in complications [5].

In GCC we treat skin tumors according to the following rules (Table 5).

\section{Conclusions}

Brachytherapy is a highly effective treatment method of skin tumors, well known for almost one hundred years, with a big number of confirmed published positive results. The complications rate is acceptable and

Table 5. Recommendations for skin cancer brachytherapy (source: Greater Poland Cancer Center, Poznan, Poland)

\begin{tabular}{|c|c|c|c|c|}
\hline Treatment & Indications & Technique & $\begin{array}{l}\text { Fraction dose } \\
\quad \text { (range) }\end{array}$ & Total dose (range) \\
\hline \multirow[t]{2}{*}{ Radical } & \multirow{2}{*}{$\begin{array}{c}\text { Primary, recurrences. Diameter }<5-6 \mathrm{~cm} \text {, technically possible } \\
\text { application, thickness }<2 \mathrm{~cm}\end{array}$} & HDR & 5.0-10.0 Gy & 50-60.0 Gy \\
\hline & & PDR & 1.0 Gy (pulse) & $\begin{array}{l}50-60.0 \text { Gy } \\
\text { (in } 2-3 \text { fractions) }\end{array}$ \\
\hline \multirow{2}{*}{$\begin{array}{l}\text { Radical, } \\
\text { after } \\
\text { surgery }\end{array}$} & \multirow{2}{*}{$\begin{array}{l}\text { Typically after non radical surgery (suggested by pathological } \\
\text { diagnosis), healthy tissue margin }<5 \mathrm{~mm}\end{array}$} & HDR & 5.0-10.0 Gy & 50-60.0 Gy \\
\hline & & PDR & 1.0 Gy (pulse) & $\begin{array}{c}50-60.0 \text { Gy } \\
\text { (in } 2-3 \text { fractions) }\end{array}$ \\
\hline \multirow[t]{2}{*}{ Palliative } & \multirow{2}{*}{$\begin{array}{c}\text { Inoperative tumors, size preventing coverage with curative } \\
\text { dose, thickness }>2 \mathrm{~cm}\end{array}$} & HDR & 5.0-10.0 Gy & 20-40.0 Gy \\
\hline & & PDR & 1.0 Gy (pulse) & $\begin{array}{l}\text { 20-40.0 Gy } \\
\text { (in } 1-2 \text { fractions) }\end{array}$ \\
\hline
\end{tabular}


treatment costs are low. Treatment is possible almost in all cases on an outpatient basis. In some tumors (great skin lesions in the scalp, near eyes or on the nose) BT allows for a great dose reduction in surrounding healthy tissues. Brachytherapy provides minimal dose delivery to surrounding healthy tissue, thus enabling good functional and cosmetic results.

\section{Conflict of interest}

The author declares no conflict of interest.

\section{References}

1. Szewczyk MP, Pazdrowski J, Dańczak-Pazdrowska A, et al. Analysis of selected recurrence risk factors after treatment of head and neck basal cell carcinoma. Postep Derm Alergol 2014; 31: 146-51.

2. Sobjanek M, Dobosz M, Pęksa R, et al. Lymphoepitheliomalike carcinoma of the skin in a Polish patient. Postep Derm Alergol 2015; 32: 56-8.

3. Marek L, Grzanka A, Chmielowska E, et al. Merkel cell carcinoma: an illustrative case and review. Postep Derm Alergol 2014; 31: 325-8.

4. Sopata M, Tomaszewska E, Muszyński Z, et al. The pilot study assessing efficacy and versatility of novel therapy for neoplastic ulceration: clinical and microbiological aspects. Postep Derm Alergol 2013; 30: 237-45.

5. Gerbaulet A, Potter R, Mazeron JJ, et al. (eds). The GEC ESTRO Handbook of Brachytherapy. ESTRO, Bruksela 2002.

6. Perez CA, Brady LW. Principles and practice of radiation oncology. 3rd ed. 1997; 723-44.

7. Chicheł A, Skowronek J. Współczesne leczenie raka skóry dermatologia, chirurgia czy radioterapia? Contemp Oncol (Poznan) 2005; 10: 429-35.

8. Malicki J, Łobodziec W, Ślósarek K. Dose-rate distribution under partially shielded beams. Strahlenther Onkol 1990; 166: 733-7.

9. Leibel SA, Philips TL (eds). Textbook of radiation oncology. Saunders, Philadelphia 2004; 316.

10. Alam M, Nanda S, Mittal BB, et al. The use of brachytherapy in the treatment of nonmelanoma skin cancer: a review. J Am Acad Dermatol 2011; 65: 377-88.

11. Delannes M, Rio E, Mirabel X, et al. Brachytherapy for cutaneous and lip carcinomas. Cancer Radiother 2013; 17: 136-9.

12. Lukačko P, Pobijáková M, Lederleitner D, et al. HDR brachytherapy for skin carcinoma of the face: treatment by customized mask - case report. J Contemp Brachytherapy 2009; 1: 186 (abstract).

13. Kowalik $九$, Łyczek J, Sawicki M, et al. Individual applicator for brachytherapy for various sites of superficial malignant lesions. J Contemp Brachytherapy 2013; 5: 45-9.

14. Kordek R, Jassem J (eds). Podręcznik dla studentów i lekarzy. Warsaw 2003; 217-21.

15. Guix B, Finestres F, Tello Jl, et al. Treatment of skin carcinomas of the face by high-dose-rate brachyterapy and custommade surface molds. Int J Radiat Oncol Biol Phys 2000; 47: 95-102.

16. Skowronek J, Chicheł A, Piotrowski T. Brachyterapia HDR nowotworów skóry - doświadczenie Wielkopolskiego Centrum Onkologii. Contemp Oncol (Poznan) 2005; 8: 347-54.

17. Garcia-Martinez T, Chan JP, Perez-Calatayud J, et al. Dosimetric characteristics of a new unit for electronic skin brachytherapy. J Contemp Brachytherapy 2014; 6: 45-53.
18. Van der Laarse R. Optimization of high dose rate brachytherapy. Activity: The Selectron User's Newsletter 1989; 2: 14-5.

19. Flynn A. Quality assurance checks on a microSelectron-HDR. Selectron Brachytherapy J 1990; 4: 112-5.

20. Lliso F, Granero D, Perez-Calatayud J, et al. Dosimetric evaluation of internal shielding in a high dose rate skin applicator. J Contemp Brachytherapy 2011; 3: 32-5.

21. Lasota J, Kabacińska R, Makarewicz R. Dose estimation for different skin models in interstitial breast brachytherapy. J Contemp Brachytherapy 2014; 6: 200-7.

22. Nag S, Caro ER, Demanes JD, et al. The American Brachytherapy Society recommendations for high dose rate brachytherapy for head and neck carcinoma. Int J Oncol Biol Phys 2001; 50: 1190-8.

23. Toller G, Lakosi F, Antal G, et al. CT assisted 3D high-doserate brachytherapy (HDR-BT) in the treatment of skin carcinoma. J Contemp Brachyther 2009; 1: 190-1.

24. Rio E, Bardet E, Ferron C, et al. Interstitial brachytherapy of periorificial skin carcinomas of the face: a retrospective study of 97 cases. Int J Radiation Oncology Biol Phys 2005; 63: 753-7.

25. Bhatnagar A. Nonmelanoma skin cancer treated with electronic brachytherapy: results at 1 year. Brachytherapy 2013; 12: $134-40$.

26. Garcia-Martinez T, Chan JP, Perez-Calatayud J, et al. Dosimetric characteristics of a new unit for electronic skin brachytherapy. J Contemp Brachytherapy 2014; 6: 45-53.

27. Kanikowski M. HDR brachytherapy of skin cancer in material of Greater Poland Cancer Center. J Contemp Brachytherapy 2009; 1: 197 (Abstract).

28. Crook JM, Mazeron JJ, Marinello G, et al. Interstitial irydium 192 for cutaneous carcinoma of the external nose. Int I Radiat Oncol Biol Phys 1990; 18: 243-8.

29. Debois JM. Cesium-137 brachytherapy for epithelioma of the skin of the nose: experience with 370 patients. JBR-BTR 1994; 77: 1-4.

30. Gambaro G, Negri E. Interstitial brachytherapy with irydium-192 for carcinomas of the eyelid and inner canthus. Radiother Oncol 2001; 60 (Suppl. 1): 16 (abstract).

31. Maes A, Van Limbergen E. LDR - Brachytherapy (BT) for non-melanoma skin cancer of the face: local control rate, functional and cosmetic outcome in 173 patients. Radiother Oncol 2001; 60 (Suppl. 1): 16 (abstract).

32. Ashby MA, Pacella JA, De Groot R, et al. Use of radon mould technique for skin cancer: results from the Peter MacCallum Cancer Institute. Br J Radiol 1989; 62: 608-12.

33. Daly NJ, Lafontan B, Combes PF. Results of the treatment of 165 lid carcinomas by iridium wire implant. Int J Radiat Oncol Biol Phys 1984; 10: 455-9.

34. Svoboda VHJ, Kovarik J, Morris F. High dose rate microselectron molds in the treatment of skin tumors. Int J Radiat Oncol Biol Phys 1995; 31: 967-72.

35. Mazeron JJ, Ghalie R, Zeller J, et al. Radiation therapy for carcinoma of the pinna using irydium 192 wires: a series of 70 patients. Int J Radiat Oncol boil Phys 1986; 12: 1757-63.

36. Tormo A, Celada F, Rodriguez S, et al. Non-melanoma skin cancer treated with HDR Valencia applicator: clinical outcomes. J Contemp Brachytherapy 2014; 6: 167-72.

37. Gauden R, Pracy M, Avery AM, et al. HDR brachytherapy for superficial non-melanoma skin cancers. J Med Imaging Radiat Oncol 2013; 57: 212-7.

38. Arguis M, Murcia-Mejía M, Henríquez I, et al. The role of HDR brachytherapy in non-melanoma skin cancer treatment. Radiother Oncol 2012; 103 Suppl. 1: S477. 